\title{
Anti-MMP-2 Activity and Skin-Penetrating Capability of the Chemical Constituents from Rhodiola rosea
}

Authors

Affiliations
Tzong-Huei Lee ${ }^{1}$, Chieh-Chih Hsu ${ }^{2}$, George Hsiao ${ }^{3}$, Jia-You Fang ${ }^{4,5}$, Wei-Min Liu ${ }^{6}$, Ching-Kuo Lee ${ }^{2,7}$

The affiliations are listed at the end of the article

\author{
Key words \\ - Rhodiola rosea \\ - Crassulaceae \\ - matrix metalloproteinase \\ - collagenase \\ 1,2,3,6-tetra-O-gal- \\ loyl-4-O-p-hydroxyben- \\ zoyl- $\beta$-D-glucopyranoside \\ (E)-creoside I \\ ( (Z)-2-methyl-2-hep- \\ ten-1,6-diol
}

received October 16, 2015 revised Nov. 30, 2015 accepted Dec. 28, 2015

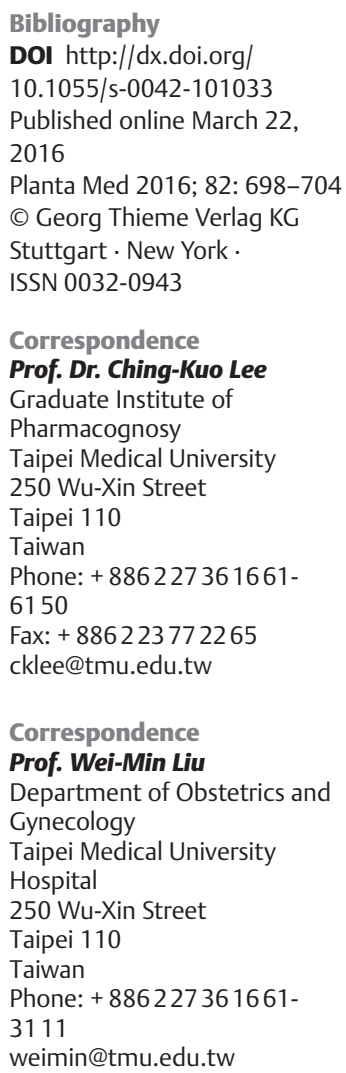

\section{Abstract \\ $\nabla$}

Based on the significant inhibitory activity toward matrix metalloproteinase- 2 and collagenase noticed in preliminary studies, crude extracts of Rhodiola rosea were partitioned and chromatographed sequentially to afford three new compounds, 1,2,3,6-tetra-O-galloyl-4-O-p-hydroxybenzoyl- $\beta$-D-glucopyranoside ( 1$)$, (E)-creoside I (2), and (R,Z)-2-methylhept-2-ene-1,6-diol (3), along with twenty-four known compounds (427). Their structures were determined by spectroscopic data analyses. All isolated compounds were subjected to bioactivity assays. In these, $\mathbf{1}$ specifically inhibited matrix metalloproteinase-2 activity with an $\mathrm{IC}_{50}$ value of $16.3 \pm 1.6 \mu \mathrm{M}$, while its analogue 1,2,3,6-tetra- $O$-galloyl- $\beta$-D-gluco-

\section{Introduction}

\section{$\nabla$}

Matrix metalloproteinases (MMPs) are a family of zinc- and calcium-dependent endopeptidases, which are grouped into the metzincin clan of metallopeptidases (MPs) together with other families such as ADAMs/adamalysins, astacins, fragilysins, and serralysins. MMPs are found throughout the animal and plant kingdoms, where their distribution is consistent with a Darwinian tree-based pathway [1]. Furthermore, polyplication has led to the presence of several paralogous MMP genes in the same organism: 24 in humans, 26 in sea urchins, 26 in zebrafish, 7 in sea squirts, and 2 in fruit flies. Overexpression of MMPs may cause various inflammatory, malignant, and degenerative symptoms [2]. Among the MMPs studied, gelatinase-A (MMP-2), gelatinase-B (MMP-9), and collagenase-1 (MMP-1) were reported to be responsible for the signal transduction of dermal photoaging [3], and inhibition of the activities of these two enzymes could potentially slow down skin aging. Thus, the search pyranonoside (17) inhibited matrix metalloproteinase- 2 with an $\mathrm{IC}_{50}$ value of $23.0 \pm 4.8 \mu \mathrm{M}$. In the collagenase activity assay, the inhibitory effects of 1 and 17 at concentrations of both 20 and $40 \mu \mathrm{M}$ were more potent than those of the positive control, 1,10-phenanthroline. In order to realize whether 17 could penetrate from the epidermal layer into the basal and dermal layers of the human skin to inhibit the activity of matrix metalloproteinase- 2 and collagenase or not, a transdermal penetration test in nude and white mice skins was performed. Penetration percentages of 17 quantified by LC-MS were $27.8 \%$ and $74.8 \%$ in 24 hours, respectively.

Supporting information available online at http://www.thieme-connect.de/products

for bioactive compounds that can regulate the activities of MMP-1, -2, and -9 from natural resources is one of the key steps in delaying skin aging.

Rhodiola rosea L. (Crassulaceae), an herbaceous plant, is used in Asian and Eastern European traditional medicines for its pressure-reducing [4], neurosystem-stimulating [5], fatigue-removing [6], hypobaropathy-preventing [7], antidepressive [7], anticancer [8], antiaging [9], cardiovascular-protective [10], and hepatoprotective effects [11]. Chemical investigations on this plant have revealed many chemical entities, including phenolic acids [12], phenolethanoids [13], phenylpropenoids [14], flavonoids [15], monoterpenes [4], and glycosides [16]. In a preliminary biological evaluation, crude extracts of $R$. rosea roots exhibited inhibitory activities toward MMP-2 and collagenase at a concentration of $100 \mu \mathrm{g} / \mathrm{mL}$ [17]. An investigation of the active principles of this plant was thus undertaken by using a bioassayguided method. Of the tested water, $n$-butanol, and ethyl acetate layers, the ethyl acetate layer 


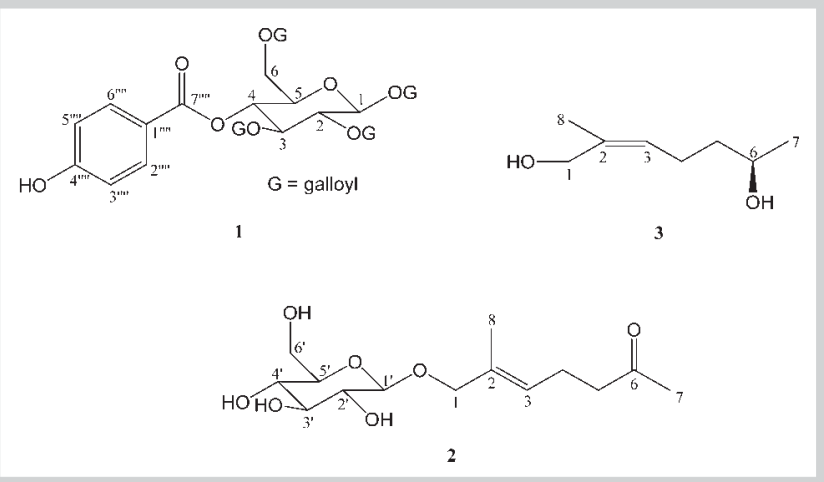

Fig. 1 Structures of compounds 1-3 isolated from the roots of $R$. rosea.

was the most potent. The subsequent isolation and identification of bioactive components was focused on this layer and led to the isolation and characterization of three new compounds (1-3; - Fig. 1) and twenty-four known compounds (4-27). The isolation and structural elucidation of the previously unreported compounds are described in this paper along with their bioactivities.

\section{Results and Discussion \\ $\nabla$}

An ethanolic extract of the roots of $R$. rosea was partitioned in a preliminary manner to give an ethyl acetate soluble layer. Flash column separation of this layer over silica gel afforded three previously unreported chemical entities (1-3) along with twentyfour known compounds. The known compounds were identified to be methyl 4-hydroxybenzoate (4) [18], $\beta$-sitosterol (5) [19], (Z)-2-methyl-6-oxo-2-hepten-1-ol (6) [20], gallic acid (7) [21], 4-hydroxyphenyl-2-ethyl $\beta$-D-glucopyranoside (8) [22], tyrosol (9) [23], methyl gallate (10) [24], p-coumaric acid (11) [25], caffeic acid (12) [25], aspergillol B (13) [26], 2R,3R-dihydrokaempferol (14) [27], (E)-2-methyl-6-oxo-2-hepten-1-ol (15) [17], 1,2,6-tri- $O$-galloyl- $\beta$-D-glucopyranonoside (16) [28], 1,2,3,6-tetra-O-galloyl- $\beta$-D-glucopyranonoside (17) [28], p-hydroxyphenethyl alcohol 1-O-D-(6"-O-galloyl)-glucopyranoside (18) [29], herbacetin 7-O- $\alpha$-L-rhammopyranoside (19) [30], kaempferol 30 - $\alpha$-L-rhammopyranoside (20) [30], epicatechin-3-O-gallate (21) [31], 1,1-dimethylprop-2-en-1-yl- $\beta$-D-glucopyranoside (22) [20], 3-methyl-but-2-en-1-yl- $\beta$-D-glucopyranoside (23) [32], (Z)-creoside I (24) [33], creoside III (25) [33], salidroside (26) [34], and icariside D2 (27) [35] based on spectroscopic data analysis and comparison to the literature.

Compound 1, obtained as amorphous white powder, had a formula of $\mathrm{C}_{41} \mathrm{H}_{32} \mathrm{O}_{24}$, as determined using ${ }^{13} \mathrm{C}$ NMR ( Table 1 ), as well as a pseudo-molecular ion $[\mathrm{M}-\mathrm{H}]^{-}$at $\mathrm{m} / \mathrm{z} 907.1241$ in negative ion high-resolution electrospray ionization mass spectrometry (HR-ESIMS). IR absorption bands of 1 showed a conjugated ester carbonyl $\left(1702 \mathrm{~cm}^{-1}\right)$ along with aromatic functionalities (1609 and $1536 \mathrm{~cm}^{-1}$ ). In the ${ }^{1} \mathrm{H}$ NMR spectrum of 1 ( Table 1 ), signals at $\delta_{\mathrm{H}} 6.24(1 \mathrm{H}, \mathrm{d}, J=8.3 \mathrm{~Hz}, \mathrm{H}-1), 5.58(1 \mathrm{H}, \mathrm{dd}, J=8.3$, $9.6 \mathrm{~Hz}, \mathrm{H}-2), 5.91(1 \mathrm{H}, \mathrm{t}, J=9.6 \mathrm{~Hz}, \mathrm{H}-3), 5.63(1 \mathrm{H}, \mathrm{t}, J=9.6 \mathrm{~Hz}, \mathrm{H}-$ 4), 4.40 (1 H, H-5), 4.41 (1 H, H-6a), 4.51 (1 H, d, J=10.3 Hz, H-6b), 7.05 (2 H, s, H-2', -6'), 6.95 (2 H, s, H-2", -6"), 6.80 (2 H, s, H-2"', $\left.-6^{\prime \prime \prime}\right)$, and $7.10\left(2 \mathrm{H}, \mathrm{s}, \mathrm{H}-2^{\prime \prime \prime \prime \prime},-6^{\prime \prime \prime \prime \prime}\right)$ were attributable to a $\beta$-Dglucopyranoside bearing four galloyl groups at C-1, $-2,-3$, and C-
Table $1{ }^{13} \mathrm{C}(125 \mathrm{MHz})$ and ${ }^{1} \mathrm{H}$ NMR $(500 \mathrm{MHz})$ data for compound 1 (in $\left.\mathrm{CD}_{3} \mathrm{OD}\right)$.

\begin{tabular}{|c|c|c|}
\hline & 1 & \\
\hline Position & ${ }^{13} \mathrm{C}$ & ${ }^{1} \mathrm{H}$ \\
\hline 1 & 94.3 & $6.24(1 \mathrm{H}, \mathrm{d}, J=8.3 \mathrm{~Hz})$ \\
\hline 2 & 72.6 & $5.58(1 \mathrm{H}, \mathrm{dd}, J=8.3,9.6 \mathrm{~Hz})$ \\
\hline 3 & 74.5 & $5.91(1 \mathrm{H}, \mathrm{t}, J=9.6 \mathrm{~Hz})$ \\
\hline 4 & 70.5 & $5.63(1 \mathrm{H}, \mathrm{t}, J=9.6 \mathrm{~Hz})$ \\
\hline 5 & 74.7 & $4.40(1 \mathrm{H})^{\mathrm{a}}$ \\
\hline 6 & 63.7 & $\begin{array}{l}4.41(1 \mathrm{H})^{\mathrm{a}} \\
4.51(1 \mathrm{H}, \mathrm{d}, J=10.3 \mathrm{~Hz})\end{array}$ \\
\hline $1^{\prime}$ & 120.2 & \\
\hline $2^{\prime}, 6^{\prime}$ & 111.1 & $7.05(2 \mathrm{H}, \mathrm{s})$ \\
\hline $3^{\prime}, 5^{\prime}$ & 147.0 & \\
\hline $4^{\prime}$ & 141.2 & \\
\hline $7^{\prime}$ & 166.7 & \\
\hline $1^{\prime \prime}$ & 120.7 & \\
\hline $2^{\prime \prime}, 6^{\prime \prime}$ & 110.9 & $6.95(2 \mathrm{H}, \mathrm{s})$ \\
\hline $3^{\prime \prime}, 5^{\prime \prime}$ & 146.8 & \\
\hline $4^{\prime \prime}$ & 140.8 & \\
\hline $7^{\prime \prime}$ & 167.5 & \\
\hline $1^{\prime \prime \prime}$ & 120.7 & \\
\hline $2^{\prime \prime \prime}, 6^{\prime \prime \prime}$ & 110.8 & $6.80(2 \mathrm{H}, \mathrm{s})$ \\
\hline $3^{\prime \prime \prime}, 5^{\prime \prime \prime}$ & 146.7 & \\
\hline $4^{\prime \prime \prime}$ & 140.6 & \\
\hline $7^{\prime \prime \prime}$ & 167.8 & \\
\hline $1^{\prime \prime \prime \prime}$ & 121.5 & \\
\hline $2^{\prime \prime \prime \prime}, 6^{\prime \prime \prime \prime}$ & 133.6 & $7.78(2 \mathrm{H}, \mathrm{d}, J=8.7 \mathrm{~Hz})$ \\
\hline $3^{\prime \prime \prime \prime}, 5^{\prime \prime \prime \prime}$ & 116.7 & $6.75(2 \mathrm{H}, \mathrm{d}, J=8.7 \mathrm{~Hz})$ \\
\hline $4^{\prime \prime \prime \prime}$ & 163.3 & \\
\hline $7^{\prime \prime \prime \prime}$ & 167.1 & \\
\hline $1^{\prime \prime \prime \prime \prime}$ & 121.4 & \\
\hline $2^{\prime \prime \prime \prime \prime}, 6^{\prime \prime \prime \prime \prime}$ & 110.8 & $7.10(2 \mathrm{H}, \mathrm{s})$ \\
\hline $3^{\prime \prime \prime \prime \prime}, 5^{\prime \prime \prime \prime \prime}$ & 146.9 & \\
\hline $4^{\prime \prime \prime \prime \prime}$ & 140.4 & \\
\hline $7^{\prime \prime \prime \prime \prime}$ & 168.4 & \\
\hline
\end{tabular}

a Signals without multiplicity were overlapped and picked up from the HSQC spectrum

6 via ester linkages; this conclusion was corroborated by the large mutual coupled $J$ values of $\mathrm{H}-1-\mathrm{H}-5$ and heteronuclear longrange correlations in the heteronuclear multiple-bond correlation (HMBC) experiment ( $\bigcirc$ Fig. 2A). Two additional mutual coupled resonances at $\delta_{\mathrm{H}} 6.75(2 \mathrm{H}, \mathrm{d}, J=8.7 \mathrm{~Hz})$ and $7.78(2 \mathrm{H}, \mathrm{d}$, $J=8.7 \mathrm{~Hz}$ ) were characteristic signals for $p$-hydroxybenzoyl located at CO-4 as evidenced by a cross-peak of $\mathrm{H}-4 / 7^{\prime \prime \prime}$ in the HMBC spectrum. Accordingly, 1 was determined as shown and named 1,2,3,6-tetra-O-galloyl-4-O-p-hydroxybenzoyl- $\beta$-D-glucopyranoside.

Compound $\mathbf{2}$ was isolated as amorphous white powder with the molecular formula $\mathrm{C}_{14} \mathrm{H}_{24} \mathrm{O}_{7}$, as determined by positive ion $\mathrm{HR}$ ESIMS, and showed an $[\mathrm{M}+\mathrm{Na}]^{+}$ion at $\mathrm{m} / z 327.1428$ (calcd. for $\mathrm{C}_{14} \mathrm{H}_{24} \mathrm{O}_{7} \mathrm{Na}$, 327.1420). Conspicuous absorptions at 3389 and $1689 \mathrm{~cm}^{-1}$ in the IR spectrum of $\mathbf{2}$ indicated the presence of hydroxyl and ketone functionalities, respectively. The ${ }^{1} \mathrm{H}$ NMR ( Table 2) spectrum coupled with the correlation spectroscopy (COSY) spectrum of 2 showed signals at $\delta_{\mathrm{H}} 4.22(1 \mathrm{H}, \mathrm{d}$, $\left.J=8.0 \mathrm{~Hz}, \mathrm{H}-1^{\prime}\right), 3.18\left(1 \mathrm{H}, \mathrm{dd}, J=8.0,8.5 \mathrm{~Hz}, \mathrm{H}-2^{\prime}\right), 3.33(1 \mathrm{H}, \mathrm{t}$, $\left.J=8.5 \mathrm{~Hz}, \mathrm{H}-3^{\prime}\right), 3.27\left(1 \mathrm{H}, \mathrm{t}, J=8.5 \mathrm{~Hz}, \mathrm{H}-4^{\prime}\right), 3.22\left(1 \mathrm{H}, \mathrm{m}, \mathrm{H}-5^{\prime}\right)$, $3.65(1 \mathrm{H}, \mathrm{dd}, J=5.5,11.5 \mathrm{~Hz}, \mathrm{H}-6 \mathrm{a}$ ) $)$, and $3.85(1 \mathrm{H}, \mathrm{dd}, J=2.0$, $\left.11.5 \mathrm{~Hz}, \mathrm{H}-6^{\prime} \mathrm{b}\right)$, indicating a $\beta$-D-glucopyranoside moiety. Further, the ${ }^{1} \mathrm{H},{ }^{13} \mathrm{C}$ NMR, COSY, and heteronuclear multiple-quantum correlation (HMQC) spectra of $\mathbf{2}$ indicated the presence of 


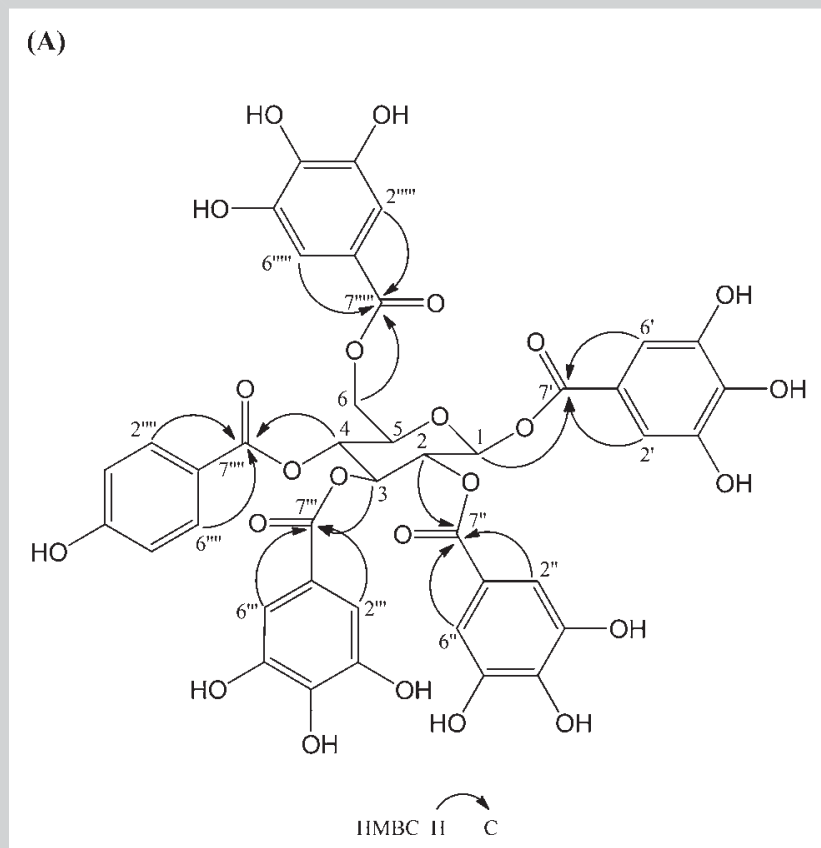

(B)

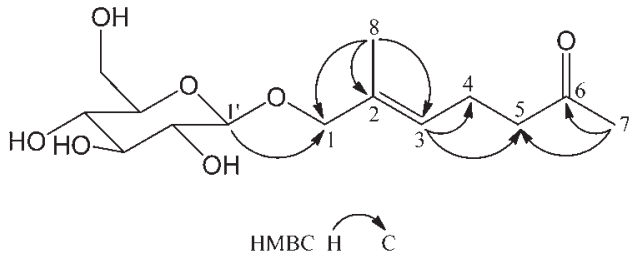

Fig. 2 Selected HMBC spectra of compounds 1 (A) and 2 (B).

two methyls $\left[\delta_{\mathrm{H}} 2.12\left(3 \mathrm{H}, \mathrm{s}, \mathrm{H}_{3}-7\right)\right.$ and $\left.1.69\left(3 \mathrm{H}, \mathrm{s}, \mathrm{H}_{3}-8\right)\right]$ in the residual aglycone part, three methylenes $\left[\delta_{\mathrm{H}}\right.$ germinal coupled 4.02 and 4.18 (each $1 \mathrm{H}, \mathrm{d}, J=11.5 \mathrm{~Hz}, \mathrm{H}_{2}-1$ ), vicinal coupling [2.28 $\left(2 \mathrm{H}, \mathrm{m}, \mathrm{H}_{2}-4\right)$ and $2.53\left(2 \mathrm{H}, \mathrm{t}, \mathrm{J}=7.0 \mathrm{~Hz}, \mathrm{H}_{2}-5\right)$ ], and an olefinic methine $\left[\delta_{\mathrm{H}} 5.42(1 \mathrm{H}, \mathrm{t}, J=6.5 \mathrm{~Hz}, \mathrm{H}-3)\right]$. In the HMBC spectrum of 2 ( Fig. 2B), cross-peaks of $\delta_{\mathrm{H}} 1.69\left(\mathrm{H}_{3}-8\right) / \delta_{\mathrm{C}} 75.6(\mathrm{C}-1)$, $133.9(\mathrm{C}-2)$ and $128.3(\mathrm{C}-3), \delta_{\mathrm{H}} 5.42(\mathrm{H}-3) / \delta_{\mathrm{C}} 23.0(\mathrm{C}-4)$ and 43.7
$(\mathrm{C}-5), \delta_{\mathrm{H}} 2.12\left(\mathrm{H}_{3}-7\right) / \delta_{\mathrm{C}} 211.4(\mathrm{C}-6)$ and $43.7(\mathrm{C}-5)$ and $\delta_{\mathrm{H}} 4.22(\mathrm{H}-$ $\left.1^{\prime}\right) / \delta_{\mathrm{C}} 75.6(\mathrm{C}-1)$ indicated that the aglycone of 2 was connected with the $\mathrm{C}-1^{\prime}$ of $\beta$-D-glucopyranoside via an ether linkage to form creoside I. The configuration of $\Delta^{2}$ was determined to be in $\mathrm{E}$ form owing to the $\delta_{\mathrm{C}} 14.1$ of C-8 in 2 in contrast with $\delta_{\mathrm{C}} 21.9$ of C-8 in (Z)-creoside I (25). Consequently, the structure of $\mathbf{2}$ was elucidated as shown and the compound was named $(E)$-creoside I.

Compound 3 was obtained as oil with an optical rotation $[\alpha]_{D}^{25}=$ $-42.2^{\circ}$ (c $0.23, \mathrm{MeOH}$ ). Comparison of the ${ }^{1} \mathrm{H}$ and ${ }^{13} \mathrm{C}$ NMR spectra of $\mathbf{3}$ and 2 revealed the major distinctive differences to be primary alcohol $\left(\delta_{\mathrm{C}} 60.0, \mathrm{C}-1\right)$, a secondary hydroxyl group $\left(\delta_{\mathrm{C}} 66.5\right.$, C-6), and $\mathrm{Z}$ form $\Delta^{2}\left(\delta_{\mathrm{C}} 20.2, \mathrm{C}-8\right)$ in 3 as opposed to the ether group $\left(\delta_{\mathrm{C}} 75.6, \mathrm{C}-1\right)$, ketone group $\left(\delta_{\mathrm{C}} 211.4, \mathrm{C}-6\right)$, and $\mathrm{E}$ form $\Delta^{2}$ $\left(\delta_{C} 14.1, \mathrm{C}-8\right)$ in 2 , respectively. The configuration of the $\Delta^{2}$ in 3 was also verified by a nuclear Overhauser effect (NOE) enhancement signal of $\mathrm{H}_{3}-8$ at $\delta_{\mathrm{H}} 1.75$ after radiation of $\mathrm{H}-3$ at $\delta_{\mathrm{H}}$ 5.27 , which indicated a $\mathrm{Z}$ form double bond. The chirality of C- 6 was determined to be $R$ by comparing the optical rotation of 3 , $[\alpha]_{\mathrm{D}}^{25}-42.2^{\circ}$, with that of $(R)-6$-methylhept-5-en-2-ol, $[\alpha]_{\mathrm{D}}$ $-14.5^{\circ}$ [36]. Thus, compound 3 was assigned as shown and named $(R, Z)$-2-methylhept-2-ene-1,6-diol.

In the MMP inhibitory activity assay, 1,2,3,6-tetra-O-galloyl-4-Op-hydroxybenzoyl- $\beta$-D-glucopyranoside (1) inhibited MMP-2 activity with an $\mathrm{IC}_{50}$ of $16.3 \pm 1.6 \mu \mathrm{M}$, while its analog 1,2,3,6-tetra$O$-galloyl- $\beta$-D-glucopyranonoside (17) inhibited MMP-2 with an $\mathrm{IC}_{50}$ value of $23.0 \pm 4.8 \mu \mathrm{M}$. In the collagenase inhibitory activity assay, the effects of $\mathbf{1}$ and $\mathbf{1 7}$ at concentrations of both 20 and $40 \mu \mathrm{M}$ were significant and more potent than those of the positive control, 1,10-phenanthroline ( $\bullet$ Table 3 ). When a concentration of $20 \mu \mathrm{M}$ of compound 17 was applied, an inhibitory activity of over $50 \%$ could be achieved. Owing to its promising activity in the enzymatic assay and in an attempt to realize whether $\mathbf{1 7}$ could penetrate from the epidermal layer into the basal and dermal layers of human skin or not, a transdermal penetration assay of $\mathbf{1 7}$ was performed using nude and white mouse skins. The nude mouse skin with sparse hair follicles mimicked human skin, and the white mouse skin with compact hair follicles was used for comparison. The transdermal penetration percentages of $\mathbf{1 7}$ in the nude mouse skin and the white mouse skin were $27.8 \%$ and $74.8 \%$ ( Table 4), respectively, in $24 \mathrm{~h}$ as determined by using LC-MS. In the same conditions, the transdermal penetration percentage of genistein, a positive control used in this study, was $3.7 \%$. Compound 17 was thus speculated to be able to pene-

\begin{tabular}{|c|c|c|c|c|}
\hline \multirow[b]{2}{*}{ Position } & \multicolumn{2}{|l|}{2} & \multicolumn{2}{|l|}{3} \\
\hline & ${ }^{13} \mathrm{C}$ & ${ }^{1} \mathrm{H}$ & ${ }^{13} \mathrm{C}$ & ${ }^{1} \mathrm{H}$ \\
\hline \multirow[t]{2}{*}{1} & \multirow[t]{2}{*}{75.6} & $4.02(1 \mathrm{H}, \mathrm{d}, J=11.5 \mathrm{~Hz})$ & \multirow[t]{2}{*}{60.0} & $4.04(1 \mathrm{H}, \mathrm{d}, J=12.0 \mathrm{~Hz})$ \\
\hline & & $4.18(1 \mathrm{H}, \mathrm{d}, J=11.5 \mathrm{~Hz})$ & & $4.08(1 \mathrm{H}, \mathrm{d}, J=12.0 \mathrm{~Hz})$ \\
\hline 2 & 133.9 & & 134.6 & \\
\hline 3 & 128.3 & $5.42(1 \mathrm{H}, \mathrm{t}, J=6.5 \mathrm{~Hz})$ & 127.2 & $5.27(1 \mathrm{H}, \mathrm{t}, J=7.0 \mathrm{~Hz})$ \\
\hline 4 & 23.0 & $2.28(2 \mathrm{H}, \mathrm{m})$ & 23.5 & $2.11(2 \mathrm{H}, \mathrm{m})$ \\
\hline 5 & 43.7 & $2.53(2 \mathrm{H}, \mathrm{t}, J=7.0 \mathrm{~Hz})$ & 38.9 & $1.45(1 \mathrm{H}, \mathrm{m})$ \\
\hline 6 & 211.4 & & 66.5 & $3.70(2 \mathrm{H}, \mathrm{m})$ \\
\hline 7 & 29.8 & $2.12(3 \mathrm{H}, \mathrm{s})$ & 22.1 & $1.14(3 \mathrm{H}, \mathrm{d}, J=6.5 \mathrm{~Hz})$ \\
\hline 8 & 14.1 & $1.69(3 \mathrm{H}, \mathrm{s})$ & 20.2 & $1.75(3 \mathrm{H}, \mathrm{s})$ \\
\hline $1^{\prime}$ & 102.6 & $4.22(1 \mathrm{H}, \mathrm{d}, J=8.0 \mathrm{~Hz})$ & & \\
\hline $2^{\prime}$ & 75.1 & $3.18(1 \mathrm{H}, \mathrm{dd}, J=8.0,8.5 \mathrm{~Hz})$ & & \\
\hline $3^{\prime}$ & 78.2 & $3.33(1 \mathrm{H}, \mathrm{t}, \mathrm{J}=8.5 \mathrm{~Hz})$ & & \\
\hline $4^{\prime}$ & 71.7 & $3.27(1 \mathrm{H}, \mathrm{t}, J=8.5 \mathrm{~Hz})$ & & \\
\hline $5^{\prime}$ & 77.9 & $3.22(1 \mathrm{H}, \mathrm{m})$ & & \\
\hline $6^{\prime}$ & 62.8 & $3.65(1 \mathrm{H}, \mathrm{dd}, J=5.5,11.5 \mathrm{~Hz})$ & & \\
\hline & & $3.85(1 \mathrm{H}, \mathrm{dd}, J=2.0,11.5 \mathrm{~Hz})$ & & \\
\hline
\end{tabular}

Table $2{ }^{13} \mathrm{C}(125 \mathrm{MHz})$ and ${ }^{1} \mathrm{H}$ NMR $(500 \mathrm{MHz})$ data for compounds 2 and $\mathbf{3}$ (in $\mathrm{CD}_{3} \mathrm{OD}$ ). 
Table 3 The inhibitory effects of compounds 1 and 17 on collagenase activity.

\begin{tabular}{|lllllll} 
Samples & $\mathbf{1}$ & & $\mathbf{1 7}$ & \multicolumn{3}{c}{ Positive control } \\
& $\mathbf{2 0 \mu \mathrm { M }}$ & $\mathbf{4 0 \mu \mathrm { M }}$ & $\mathbf{2 0 \mu \mathrm { M }}$ & $\mathbf{4 0 \mu \mathrm { M }}$ & $\mathbf{2 0 \mu \mathrm { M }}$ & $\mathbf{4 0 \mu \mathrm { M }}$ \\
\hline Inhibitory effectiveness (\%) & $23.51 \pm 2.81^{*}$ & $47.50 \pm 2.90$ & $52.12 \pm 4.30^{* * *}$ & $61.73 \pm 1.98^{* *}$ & $12.80 \pm 5.40$ & $38.41 \pm 1.43$
\end{tabular}

The percentual inhibition is shown as mean \pm SD of three independent experiments. ${ }^{*} \mathrm{P}<0.05,{ }^{* *} \mathrm{p}<0.01$, and ${ }^{* * *} \mathrm{p}<0.0001$ compared with the positive control group. Positive control: 1,10-phenanthroline

\begin{tabular}{|c|c|c|c|c|}
\hline Sample mice & & $\begin{array}{l}\text { The amount of } 17 \text { applied } \\
\text { onto the skins }(\mu \mathrm{g})\end{array}$ & Average $(\mu \mathrm{g})$ & $\begin{array}{l}\text { Penetration percentage of } 17 \\
\text { into the mouse skins (\%) }\end{array}$ \\
\hline \multirow[t]{3}{*}{ Nude mice } & 1. & 1.42 & \multirow[t]{3}{*}{$1.17 \pm 0.21$} & \multirow[t]{3}{*}{27.8} \\
\hline & 2. & 1.02 & & \\
\hline & 3. & 1.09 & & \\
\hline \multirow[t]{3}{*}{ White mice } & 4. & 8.82 & \multirow[t]{3}{*}{$6.07 \pm 2.43$} & \multirow[t]{3}{*}{74.8} \\
\hline & 5. & 4.23 & & \\
\hline & 6. & 5.16 & & \\
\hline
\end{tabular}

Table 4 Results of the transdermal penetration test of compound 17 through nude mice and white mice skins. trate from the epidermal layer into the basal and dermal layers of human skin to inhibit the activity of MMP-2 and collagenase, and to mitigate skin aging.

\section{Materials and Methods \\ $\nabla$}

\section{General experimental procedures}

Optical rotations were measured on a JASCO P-1020 polarimeter. ${ }^{1} \mathrm{H}$ and ${ }^{13} \mathrm{C}$ NMR were performed with a Bruker Avance DRX-500 spectrometer. Low- and high-resolution mass spectra were obtained using an ABI API 4000 Q-TRAP ESI-MS and a Waters LCT Premier $^{\mathrm{TM}}$ XE HR-ESI-MS, respectively. IR spectra were recorded on a JASCO FT/IR 4100 spectrometer.

\section{Chemicals and reagents}

HPLC grade solvents, $n$-hexane, ethyl acetate, methanol, and acetonitrile were purchased from J.T. Baker. Epigallocatechin gallate, genistein, and 1,10-phenanthroline (all purities > 95\%) were purchased from Sigma-Aldrich.

\section{Plant materials}

Dried roots of $R$. rosea were purchased from Scientific Pharmaceutical Elite Company (Batch No. 106), Taipei, Taiwan, on September 8, 2009. A voucher specimen (No. TMU090908) was identified by Hsiu-Wen Huang, Taiwan Endemic Species Research Institute, ChiChi, Taiwan, and deposited at the Institute of Pharmacognosy, Taipei Medical University, Taipei, Taiwan.

\section{Extraction and isolation}

Dried roots $(10.0 \mathrm{~kg})$ of $R$. rosea were smashed and extracted three times with $40 \mathrm{~L}$ of ethanol, which was filtered and rotary evaporated to give a black residue $(1758 \mathrm{~g})$. This residue was then suspended in $\mathrm{H}_{2} \mathrm{O}(3 \mathrm{~L}$ ) and partitioned with an equal volume of ethyl acetate three times. The ethyl acetate layer was evaporated to dryness under vacuum ( $415 \mathrm{~g}$ ). Subsequently, the dried ethyl acetate layer $(250 \mathrm{~g})$ was mixed with $375 \mathrm{~g}$ of silica gel (70-230 mesh, Merck), and was loaded onto a conditioned open column packed with $3550 \mathrm{~g}$ of silica gel and eluted via a stepwise gradient method by using mixtures of $n$-hexane, ethyl acetate, and methanol. Five hundred $\mathrm{ml}$ were collected for each fraction and analyzed by TLC. TLC was performed on silica gel $60 \mathrm{~F}_{254}$ plates (Merck) by using mixtures of $n$-hexane-ethyl acetate for develop- ment, and spots were detected by spraying with vanillin-sulfuric acid followed by heating. Then, all fractions were combined into six portions (I-VI) according to the results of the TLC analyses; they were then redissolved in a minimum volume of the $n$-hexane/ethyl acetate mixtures for subsequent HPLC analysis. Portion II eluted by $n$-hexane/ethyl acetate (95:5) was purified by performing semipreparative HPLC (Hibar ${ }^{\circledR}$ Fertigsäule, $10 \times$ $250 \mathrm{~mm}$ ) using $n$-hexane/ethyl acetate (96:4) as the eluent at a flow rate of $3 \mathrm{~mL} / \mathrm{min}$ to afford $6\left(4.2 \mathrm{mg}, t_{\mathrm{R}}=19.8 \mathrm{~min}\right), 3$ $\left(6.1 \mathrm{mg}, t_{\mathrm{R}}=21.2 \mathrm{~min}\right), 5\left(32 \mathrm{mg}, t_{\mathrm{R}}=23.5 \mathrm{~min}\right)$, and $7(79 \mathrm{mg}$, $\left.t_{R}=28.0 \mathrm{~min}\right)$. The same portion was purified by performing semipreparative HPLC (Phenomenex ${ }^{\circledR}$ Luna, $10 \times 250 \mathrm{~mm}$ ) using $n$-hexane/ethyl acetate $(99: 1)$ as the eluent at a flow rate of $3 \mathrm{~mL} / \mathrm{min}$ to afford 4 ( $\left.36 \mathrm{mg}, t_{\mathrm{R}}=32.5 \mathrm{~min}\right)$. Portion III, eluted by $n$-hexane/ethyl acetate $(90: 10)$, was purified by performing semipreparative HPLC (Phenomenex ${ }^{\circledR}$ Luna, $10 \times 250 \mathrm{~mm}$ ) using $n$-hexane/acetone $(99: 1)$ as the eluent at a flow rate of $3 \mathrm{~mL} /$ min to afford 8 ( $\left.1.7 \mathrm{~g}, t_{\mathrm{R}}=19.3 \mathrm{~min}\right)$. Portion IV, eluted by $n$-hexane/ethyl acetate $(80: 20)$, was purified by performing semipreparative HPLC (Phenomenex ${ }^{\circledR}$ Luna, $10 \times 250 \mathrm{~mm}$ ) using $n$-hexane/ethyl acetate $(85: 15)$ as the eluent at a flow rate of $3 \mathrm{~mL} /$ min to afford 15 (19 $\left.\mathrm{mg}, t_{\mathrm{R}}=24.4 \mathrm{~min}\right), 12\left(11 \mathrm{mg}, t_{\mathrm{R}}=26.9 \mathrm{~min}\right)$, $9\left(25 \mathrm{mg}, t_{\mathrm{R}}=33.8 \mathrm{~min}\right), \mathbf{1 0}\left(31 \mathrm{mg}, t_{\mathrm{R}}=37.0 \mathrm{~min}\right)$, and $11(24 \mathrm{mg}$, $\left.t_{R}=42.5 \mathrm{~min}\right)$. The same portion was purified using the same column by using $n$-hexane/ethyl acetate $(78: 22)$ as the eluent at a flow rate of $3 \mathrm{~mL} / \mathrm{min}$ to obtain $14\left(10 \mathrm{mg}, t_{\mathrm{R}}=20.1 \mathrm{~min}\right)$ and 13 ( $22 \mathrm{mg}, t_{\mathrm{R}}=24.6 \mathrm{~min}$ ). The same portion was purified by the same column using $n$-hexane/ethyl acetate/acetone $(85: 10: 10)$ as the eluent at a flow rate of $3 \mathrm{~mL} / \mathrm{min}$ to obtain $19\left(25 \mathrm{mg}, t_{\mathrm{R}}=\right.$ $13.2 \mathrm{~min}), 17\left(55 \mathrm{mg}, t_{\mathrm{R}}=16.3 \mathrm{~min}\right), 16\left(132 \mathrm{mg}, t_{\mathrm{R}}=21.8 \mathrm{~min}\right)$, and $18\left(39 \mathrm{mg}, t_{R}=25.6 \mathrm{~min}\right)$. Portion $V$, eluted by $n$-hexane/ethyl acetate $(60: 40)$, was purified by performing semipreparative HPLC (Hibar ${ }^{\circledR}$ Fertigsäule, $10 \times 250 \mathrm{~mm}$ ) using $n$-hexane/ethyl acetate/acetone $(68: 27: 5)$ as the eluent at a flow rate of $3 \mathrm{~mL} /$ min to afford $20\left(5.3 \mathrm{~g}, t_{\mathrm{R}}=10.2 \mathrm{~min}\right), 22\left(63 \mathrm{mg}, t_{\mathrm{R}}=20.0 \mathrm{~min}\right)$, 21 ( $\left.84 \mathrm{mg}, t_{\mathrm{R}}=22.0 \mathrm{~min}\right)$, and 23 (33 $\left.\mathrm{mg}, t_{\mathrm{R}}=26.5 \mathrm{~min}\right)$. The same portion was purified by performing semipreparative HPLC ( $\mathrm{Hi}$ bar $^{\circledR}$ Fertigsäule, $10 \times 250 \mathrm{~mm}$ ) using $n$-hexane/ethyl acetate (72:28) as the eluent at a flow rate of $3 \mathrm{~mL} / \mathrm{min}$ to afford 2 $\left(24 \mathrm{mg}, t_{\mathrm{R}}=24.3 \mathrm{~min}\right), 24$ ( $\left.4.6 \mathrm{mg}, t_{\mathrm{R}}=32.3 \mathrm{~min}\right)$, and 25 (3.3 mg, $\left.t_{\mathrm{R}}=38.7 \mathrm{~min}\right)$. Portion VI, eluted by $n$-hexane/ethyl acetate (40:60), was purified by performing semipreparative HPLC (Hibar $^{\circledR}$ Fertigsäule, $10 \times 250 \mathrm{~mm}$ ) using $n$-hexane/ethyl acetate 
(53:47) as the eluent at a flow rate of $3 \mathrm{~mL} / \mathrm{min}$ to afford 1 ( $5 \mathrm{mg}$, $\left.t_{\mathrm{R}}=13.2 \mathrm{~min}\right), 26\left(11.4 \mathrm{mg}, t_{\mathrm{R}}=21.5 \mathrm{~min}\right)$, and 27 (3.6 mg, $t_{\mathrm{R}}=30.2 \mathrm{~min}$ ).

\section{Identification of isolated compounds}

All the isolated compounds were identified by interpreting their ${ }^{1} \mathrm{H},{ }^{13} \mathrm{C}$, and 2D NMR spectra, including COSY, NOESY, HMQC, and HMBC spectra, which were further supported by IR, LR-, HR-MS, and optical rotation data.

1,2,3,6-Tetra-O-galloyl-4-O-p-hydroxybezoyl- $\beta$-D-glucopyranoside (1): Amorphous white powder; $[\alpha]_{\mathrm{D}}^{24}+38.75\left(\right.$ c $\left.0.08, \mathrm{CH}_{3} \mathrm{OH}\right)$; IR (neat) $v_{\max } 3375,1702,1609,1536$; negative HRESIMS $m / z$ $907.1241[\mathrm{M}-\mathrm{H}]^{-}$(calcd. for $\mathrm{C}_{41} \mathrm{H}_{31} \mathrm{O}_{24}, 907.1205$ ); for ${ }^{1} \mathrm{H}$ and ${ }^{13} \mathrm{C}$ NMR data see $\odot$ Table 1.

(E)-Creoside I (2): Amorphous white powder; $[\alpha]_{D}^{25}-58.0$ (c 0.05, $\mathrm{CH}_{3} \mathrm{OH}$ ); IR (neat) $v_{\max } 3389,1698$; ESIMS $m / z 327.3[\mathrm{M}+\mathrm{Na}]^{+}$; for ${ }^{1} \mathrm{H}$ and ${ }^{13} \mathrm{C}$ NMR data see $\odot$ Table 2.

(R,Z)-2-Methylhept-2-ene-1,6-diol (3): Colorless oil; $[\alpha]_{\mathrm{D}}^{25}-42.2$ (c $0.23, \mathrm{CH}_{3} \mathrm{OH}$ ); ESIMS $\mathrm{m} / z$ 166.2 $[\mathrm{M}+\mathrm{Na}]^{+}$; for ${ }^{1} \mathrm{H}$ and ${ }^{13} \mathrm{C}$ NMR data see $\bullet$ Table 2.

Matrix metalloproteinase-2 inhibitory activity assay To evaluate the MMP-2 inhibitory activity of the galloyl derivatives 1, 7, and 16-19, gelatin zymography was conducted [37]. Briefly, HT1080 cell suspension $\left(5 \times 10^{5}\right.$ cells $\left./ \mathrm{mL}\right)$ was placed in 24-well cell culture plates for $24 \mathrm{~h}$ of incubation at $37^{\circ} \mathrm{C}$. Subsequently, the cells were treated with the vehicle (DMSO), compounds 1,7 , and $16-19(10,20,50$, and $100 \mu \mathrm{M})$, or epigallocatechin gallate (EGCG, $100 \mu \mathrm{M}$ ) as a positive control followed by an incubation at $37^{\circ} \mathrm{C}$ for $24 \mathrm{~h}$. The purity of all of the tested compounds was higher than $95 \%$ as checked by HPLC. Supernatants were mixed with a sample-loading dye (the composition was $500 \mathrm{mM}$ Tris- $\mathrm{HCl}, 25 \%$ glycerol, $10 \%$ SDS, and $0.32 \%$ bromophenol blue; $\mathrm{pH} 6.8$ ) in a volume ratio of $1: 2$, followed by polyacrylamide gel electrophoresis (PAGE). The PAGE gel contained $1 \%$ gelatin and $10 \%$ polyacrylamide, where gelatin acted as a substrate for MMP-2. After electrophoresis, the gel was washed twice with $2.5 \%$ Triton X-100 at $24^{\circ} \mathrm{C}$ for 30 min to remove the dye and SDS. Afterwards, the gel was incubated with a reacting buffer $(50 \mathrm{mM}$ Tris-base, $200 \mathrm{mM} \mathrm{NaCl}, 5 \mathrm{mM} \mathrm{CaCl}_{2}$, and $0.02 \% \mathrm{Brij}_{35}$; pH 7.5) at $37^{\circ} \mathrm{C}$ for $24 \mathrm{~h}$. A fixing solution ( $7 \%$ acetic acid and $40 \%$ methanol) was subsequently applied to the gel for $30 \mathrm{~min}$, and the gel was stained with Brilliant Blue G-Colloidial, and then destained with a destain solution (10\% acetic acid and $40 \%$ methanol). Finally, the gelatinolytic zone was analyzed using an image analysis system (Vilber Lounmat). The analysis software used was Bio-1 version 99 . The formula used to determine the inhibitory effectiveness of the compounds was as follows: [(the values of blank - the values of experimental group)/the values of blank] $\times 100 \%$.

\section{Collagenase inhibitory activity assay}

$\mathrm{DQ}^{\mathrm{TM}}$ (EnzChek Gelatinase/Collagenase Assay Kit, E-12055) is a type of fluorescent material that can bond with gelatin to form DQ-gelatin. Since the capability of collagenase type IV to induce gelatin hydrolysis has been demonstrated, $\mathrm{DQ}^{\mathrm{TM}}$-gelatin can be a substrate for collagenase. Thus, the principle of this experiment was to measure the activity of collagenase by determining the emission intensity of DQ fluorescence because the chemical bond between DQ-gelatin could be enzymatically digested by collagenase. The fluorescence intensity can be measured using a florescence microplate reader equipped with standard fluorescein filters. The fluorescence absorption and emission wavelengths for the digestion product from DQ-gelatin and the DQ collagen substrate were $495 \mathrm{~nm}$ and $515 \mathrm{~nm}$, respectively. Therefore, a fluorescence emission intensity higher than that of the blank at a wavelength of $515 \mathrm{~nm}$ is an indicator of collagenase activity. In other words, the resulting fluorescence emission intensity would decrease at $515 \mathrm{~nm}$ if the collagenase inhibitors, compounds 1 and 17 , were applied. The results of the collagenase assay are presented as mean $\pm S D$ values.

\section{Transdermal penetration test}

To evaluate the effectiveness of a topical agent of compound $\mathbf{1 7}$ within a larger amount, a transdermal penetration test was performed. The apparatus used for this experiment was a Franz-type diffusion cell, consisting of a set of vertical double-diffusion and detachable glass containers. The upper donor chamber of the cell is a hollow cylinder for sample injection, the bottom contact surface of the donor chamber is provided for close integration. The lower receptor chamber is a double-layered hollow cylindrical diffusion container, of which the inner layer is made of glass, containing the fluid for sampling; the outer layer of the receptor chamber is filled with circulating water, maintained at $37 \pm 1^{\circ} \mathrm{C}$ to simulate the human body. The contact area between the donor chamber and the receptor chamber was $0.785 \mathrm{~cm}^{2}$ (the actual penetration area), and nude or white mouse $(n=3)$ skin (epidermis facing upwards) was fixed using metal clips to serve as the in vitro transdermal penetration barrier. The experimental method is presented below. First, compound $\mathbf{1 7}$ was dissolved in $\mathbf{3 0} \mathrm{wt} \%$ propylene glycol aqueous solution, followed by a transfer of $0.5 \mathrm{~mL}$ of aqueous solution (containing $0.25 \mathrm{mg}$ ) of compound 17 into the donor chamber of the Franz-type diffusion cell. The top of the open-ended donor chamber was covered tightly with Parafilm $^{\circledR}$, and the inner receptor chamber was filled with $5.5 \mathrm{~mL}$ of the buffer solution (30 wt\% ethanol and phosphate buffer solution; $\mathrm{pH} 7.4$ ), under continuously stirring at $600 \mathrm{rpm}$. The buffer solution was sampled $(0.3 \mathrm{~mL})$ at time points of $1,2,4,6,8,10,12$, 24,36 , and $48 \mathrm{~h}$, and was replaced with an equal volume $(0.3 \mathrm{~mL})$ of the buffer solution to maintain the same volume of fluid in the diffusion cell. Finally, the accumulated compound 17 in the solution in the receptor chamber was analyzed by liquid chromatography-tandem mass spectrometry (LC-MS/MS), and the results represented the amount of compound $\mathbf{1 7}$ that could penetrate through the skin and reach the blood vessels. After completing this experimental step, deionized water was used to wash compound 17 off the nude and white mouse skin surfaces. Thereafter, the skins were taken out of the apparatus and trimmed to obtain a circle with a diameter equal to that of the donor chamber by using surgical scissors, and the weight of the sample was recorded. The skin samples were then homogenized with $1 \mathrm{~mL}$ of alcohol at $300 \mathrm{rpm}$ for $5 \mathrm{~min}$, followed by centrifugation at $10000 \mathrm{rpm}$ for $5 \mathrm{~min}$. The supernatant was filtered using $0.45 \mu \mathrm{m}$ PVDF and the amount of compound $\mathbf{1 7}$ in the skin was quantified by performing LC-MS. Genistein was used as a positive control following the same method.

\section{Transdermal penetration analysis using} high-performance liquid chromatography tandem mass spectrometry

The HPLC-MS/MS apparatus used consisted of an Agilent 1100 HPLC system coupled to an Applied Biosystems 4000 triple quadrupole mass spectrometer with an electrospray ionization source for the simultaneous detection of 1,2,3,6-tetra- $O$-galloyl- $\beta$-Dglucopyranoside (17) and genistein. The chromatographic sepa- 
ration was performed on a $\mathrm{C}_{18}$ Phenomenex column (100x $4.6 \mathrm{~mm}, 5 \mu \mathrm{m})$. The injection volume was $10 \mu \mathrm{L}$. The flow rate was set to $0.5 \mathrm{~mL} / \mathrm{min}$ and the gradient used was as follows (where $\mathrm{A}=$ water and $\mathrm{B}=$ acetonitrile): $\mathrm{t}=0-1.2 \mathrm{~min}, \mathrm{~A}: \mathrm{B}(80$ : $10 \mathrm{v} / \mathrm{v}) ; \mathrm{t}=1.2-2.5 \mathrm{~min}, \mathrm{~A}: \mathrm{B}(80: 10 \mathrm{v} / \mathrm{v}) ; \mathrm{t}=2.5-3.5 \mathrm{~min}, \mathrm{~A}: \mathrm{B}$ $(80: 10 \mathrm{v} / \mathrm{v})$ to $A: B(10: 80 \mathrm{v} / \mathrm{v}) ; t=3.5-6.5 \mathrm{~min}, \mathrm{~A}: \mathrm{B}(80: 10 \mathrm{v} / \mathrm{v})$. Mass detection and quantification were performed in the negative mode using multiple reaction monitoring (MRM) of the precursor/product ion pair at $\mathrm{m} / \mathrm{z} 787 / 617$ and $269 / 133$ for compound 17 and genistein, respectively. The optimized parameters for mass detection were as follows: curtain gas, 10 psi; nebulizer gas (Gas 1), 60 psi; auxiliary gas (Gas 2), 65 psi; and turbo ion spray temperature, $425^{\circ} \mathrm{C}$. Data acquisition and processing were performed using Analyst 1.4 software (AB SCIEX).

\section{Statistical analysis}

The experimental results are expressed as mean \pm standard error. Data were assessed using the Student-Newman-Keuls test and $\mathrm{p}<0.05, \mathrm{p}<0.01$, and $\mathrm{p}<0.001$ was considered significant.

\section{Supporting information}

Spectral data of compounds $\mathbf{1 - 3}$ are available as Supporting Information.

\section{Acknowledgments \\ $\nabla$}

We are grateful to Dr. Shwu-Huey Wang, Ms. Shou-Ling Huang, and Ms. Shu-Yun Sun of the Instrumentation Center of Taipei Medical University and the Instrumentation Center of the College of Science, National Taiwan University, respectively, for NMR and MS data acquisition. We also want to thank Taipei Medical University Hospital (101 TMU-TMUH-18) and the Ministry of Science and Technology of the Republic of China for financial support (98-2320-B-038-015-MY3 and 101-2320-B-038-013-MY3).

\section{Conflict of Interest}

\section{$\nabla$}

The authors declare no conflict of interest.

\section{Affiliations}

${ }^{1}$ Institute of Fisheries Science, National Taiwan University, Taipei, Taiwan

${ }^{2}$ Graduate Institute of Pharmacognosy, Taipei Medical University, Taipei, Taiwan

${ }^{3}$ Graduate Institute of Medical Science and Department of Pharmacology, College of Medicine, Taipei Medical University, Taipei, Taiwan

${ }^{4}$ Research Center for Industry of Human Ecology, Chang Gung University of Science and Technology, Kweishan, Taoyuan, Taiwan

${ }^{5}$ Pharmaceutics Laboratory, Graduate Institute of Natural Products, Chang Gung University, Kweishan, Taoyuan, Taiwan

${ }^{6}$ Department of Obstetrics and Gynecology, Taipei Medical University Hospital, Taipei, Taiwan

${ }^{7}$ School of Pharmacy, Taipei Medical University, Taipei, Taiwan

\section{References}

1 López-Pelegrín M, Ksiazek M, Karim AY, Guevara T, Arolas JL, Potempa J, Gomis-Rüth FX. A novel mechanism of latency in matrix metalloproteinases. J Biol Chem 2015; 290: 4728-4740

2 Nicolotti O, Catto M, Giangreco I, Barletta M, Leonetti F, Stefanachi A, Pisani L, Cellamare S, Tortorella P, Loiodice F, Carotti A. Design, synthesis and biological evaluation of 5-hydroxy, 5-substituted-pyrimidine2,4,6-triones as potent inhibitors of gelatinases MMP-2 and MMP-9. Eur J Med Chem 2012; 58: 368-376

3 Bernstein EF, Uitto J. The effect of photodamage on dermal extracellular matrix. Clin Dermatol 1996; 14: 143-151
4 Brown RP, Gerbarg PL, Ramazanov Z. Rhodiola rosea: a phytochemical overview. HerbalGram 2002; 56: 40-52

5 Fan W, Tezuka Y, Ni KM, Kadota S. Prolyl endopeptidase inhibitor from the underground part of Rhodiola sachalinensis. Chem Pharm Bull (Tokyo) 2001; 49: 396-401

6 Boon-Niermeijer EK, van den Berg A, Wikman G, Wiegant FA. Phytoadaptogens protect against environmental stress-induced death of embryos from the freshwater snail Lymnaea stagnalis. Phytomedicine 2000; 7: 389-399

7 Spasov AA, Wikman GK, Mandrikov VB, Mironova IA, Neumoin VV. A double-blind, placebo-controlled pilot study of the stimulating and adaptogenic effect of Rhodiola rosea SHR-5 extract on the fatigue of students caused by stress during an examination period with a repeated low-dose regimen. Phytomedicine 2000; 7: 85-89

8 Song EK, Kim JH, Kim JS, Cho H, Nan JX, Sohn DH, Ko GI, Oh H, Kim YC. Hepatoprotective phenolic constituents of Rhodiola sachalinensis on tacrine-induced cytotoxicity in Hep G2 cells. Phytother Res 2003; 17: 563-565

9 Ohsugi M, Fan W, Hase K, Xiong Q Tezuka Y, Komatsu K, Namba T, Saitoh T, Tazawa K, Kadota S. Active oxygen scavenging activity of traditional nourishing-tonic herbal medicines and active constituents of Rhodiola sacra. J Ethnopharmacol 1999; 67: 111-119

10 Maslova LV, Kondrat'ev BIu, Maslov LN, Lishmanov I. [The cardioprotective and antiadrenergic activity of an extract of Rhodiola rosea in stress]. Eksp Klin Farmakol 1994; 57: 61-63

11 Nakamura S, Li X, Matsuda H, Ninomiya K, Morikawa T, Yamaguti $K$ Yoshikawa M. Bioactive constituents from Chinese natural medicines. XXVI. Chemical structures and hepatoprotective effects of constituents from roots of Rhodiola sachalinensis. Chem Pharm Bull (Tokyo) 2007; 55: $1505-1511$

12 Lee MW, Lee YA, Park HM, Toh SH, Lee EJ, Jang HD, Kim YH. Antioxidative phenolic compounds from the roots of Rhodiola sachalinensis A. Bor. Arch Pharm Res 2000; 23: 455-458

13 Wang H, Ding Y, Zhou J, Sun X, Wang S. The in vitro and in vivo antiviral effects of salidroside from Rhodiola rosea L. anainst coxsac-kievirus B3. Phytomedicine 2009; 16: 146-155

14 Linh PT, Kim YH, Hong SP, Jian JJ, Kang JS. Quantitative determination of salidroside and tyrosol from the underground part of Rhodiola rosea by high performance liquid chromatography. Arch Pharm Res 2000; 23: 349-352

15 Cai H, Hudson EA, Mann P, Verschoyle RD, Greaves P, Manson MM, Steward WP, Gescher AJ. Growth-inhibitory and cell cycle-arresting properties of the rice bran constituent tricin in human-derived breast cancer cells in vitro and in nude mice in vivo. Br J Cancer 2004; 91: 1364-1371

16 Nakamura S, Li X, Matsuda H, Yoshikawa M. Bioactive constituents from Chinese natural medicines. XXVIII. Chemical structures of acyclic alcohol glycosides from the roots of Rhodiola crenulata. Chem Pharm Bull (Tokyo) 2008; 56: 536-540

$17 \mathrm{Hsu}$ CC. Anti-aging constituents of Rhodiola rosea [master thesis]. Taipei, Taiwan: Taipei Medical University; 2004

18 Penner GH, Wasylishen RE. A carbon-13 CP/MAS nuclear magnetic resonance study of several 1, 4-disubstituted benzenes in the solid state. Can J Chem 1989; 67: 525-534

19 Jamal AK, Yaacob WA, Din LB. A chemical study on Phyllanthus columnaris. Eur J Sci Res 2009; 28: 76-81

20 Ahmed AA, Heqazy ME, Hassan NM, Wojcinska M, Karchesy J, Pare PW, Mabry TJ. Constituents of Chrysothamnus viscidiflorus. Phytochemistry 2006; 67: 1547-1553

21 Chen Y, Wang M, Rosen RT, Ho CT. 2,2-Diphenyl-1-picrylhydrazyl radical-scavenging active components from Polygonum multiflorum Thunb. J Agric Food Chem 1999; 47: 2226-2228

22 Lee CW, Son EM, Kim HS, Xu P, Batmunkh T, Lee BL, Koo KA. Synthetic tyrosyl gallate derivatives as potent melanin formation inhibitors. Bioorg Med Chem Lett 2007; 17: 5462-5464

23 Rasser F, Anke T, Sterner O. Secondary metabolites from a Gloeophyllum species. Phytochemistry 2000; 54: 511-516

24 Meunier SJ, Wu Q Wang SN, Roy R. Synthesis of hyperbranched glycoendrimers incorporating $\alpha$-thiosialosides based on a gallic acid core. Can J Chem 1997; 75: 1472-1482

25 DellaGreca M, Monaco P, Pinto G, Pollio A, Previtera L, Temussi F. Phytotoxicity of low-molecular-weight phenols from olive mill waste waters. Bull Environ Contam Toxicol 2001; 67: 352-359

26 Pettit GR, Jiang D, Pettit RK, Knight JC, Doubek DL. Antineoplastic agents. 575. The fungus Aspergillus phoenicis. Heterocycles 2009; 79: 909-916 
27 Baderschneider B, Winterhalter P. Isolation and characterization of novel benzoates, cinnamates, flavonoids, and lignans from Riesling wine and screening for antioxidant activity. J Agric Food Chem 2001; 49: 2788-2798

28 Owen RW, Haubner R, Hull WE, Erben G, Spiegelhalder B, Bartsch H, Haber $B$. Isolation and structure elucidation of the major individual polyphenols in carob fibre. Food Chem Toxicol 2003; 41: 1727-1738

29 Nonaka G, Nishimura H, Nishioka I. Tannins and related compounds. IV. Seven new phenol glucoside gallates from Quercus stenophylla Makino (1). Chem Pharm Bull (Tokyo) 1982; 30: 2061-2067

30 Mendez J, Bilia AR, Morelli I. Phytochemical investigations of Licania genus. Flavonoids and triterpenoids from Licania pittieri. Pharm Acta Helv 1995; 70: 223-226

31 Davis AL, Cai Y, Davies AP, Lewis JR. ${ }^{1} \mathrm{H}$ and ${ }^{13} \mathrm{C}$ NMR assignments of some green tea polyphenols. Magn Reson Chem 1996; 34: 887-890

32 Ly TN, Yamauchi R, Shimoyamada M, Kato K. Isolation and structural elucidation of some glycosides from the rhizomes of smaller galanga (Alpinia officinarum Hance). J Agric Food Chem 2002; 50: 4919-4924
33 Nakamura S, Li X, Matsada H, Yoshikawa M. Bioactive constituents from Chinese natural medicines. XXVIII. Chemical structures of acyclic alcohol glycosides from the roots of Rhodiola crenulata. Chem Pharm Bull (Tokyo) 2008; 56: 536-540

34 Schwab W, Schreiner P. Aryl $\beta$-D-glucosides from Carica papaya fruit. Phytochemistry 1988; 27: 1813-1816

35 Miyase T, Ueno A, Takizawa N, Kobayashi H, Oguchi H. Ionone and lignan glycosides from Epimedium diphyllum. Phytochemistry 1989; 28: 3483-3485

36 Fantin G, Fogagnolo M, Medici A, Pedrini P, Fontana S. Kinetic resolution of racemic secondary alcohols via oxidation with Yarrowia lipolytica strains. Tetrahedron Asymmetry 2000; 11: 2367-2373

37 Chou YC, Sheu JR, Chung CL, Chen CY, Lin FL, Hsu MJ, Kuo YH, Hsiao G. Nuclear-targeted inhibition of NF- $k$ B on MMP-9 production by N-2(4-bromophenyl) ethyl caffeamide in human monocytic cells. Chem Biol Interact 2010; 184: 403-412 